\title{
NATURE CONSERVATION IN POLAND
}

Nature Conservation in Poland is regulated by an Act of 7th April, 1949. This law reflects modern ideas of conservation and was, in fact, developed from two international nature congresses in which Poland took part-Brunnen, 1947, and Fontainebleau, 1948. The act contains a clear statement which can hardly be bettered of the purpose of nature conservation.

"Nature conservation, as understood in the present Act, means the preservation, restitution and suitable use of :-

1. Natural resources ;

2. Individual examples and accumulations of animate and inanimate nature-as well as communities in particular areas - the conservation of which is desirable in the public interest, for scientific, aesthetic or social reasons, or is dictated by the special character of the landscape."

The task of the nature conservation authorities is therefore to provide for " reasonable use of natural resources in accordance with principles aiming at safeguarding and regenerating nature's productive capacity."

\section{Organization}

Control of nature conservation in Poland rests with the Minister of Forests and Wood Industry. He appoints the Chief Conservator of Nature who is at the head of the Nature Conservation Administration being an independent department of the Ministry of Forests and Wood Industry. Both National Parks and the Breeding Centres for the European bison come under the Nature Conservation Administration. A similar organization is carried down to the Palatinate level, the Palatinate Conservator of Nature being appointed in agreement with the Minister of Forests.

All the above authorities possess executive power; other authorities must consult with them about any schemes which are likely to influence the natural equilibrium significantly. Their specific duties include the designation of nature reserves through the Minister of Forests, the establishment of national parks by an ordinance of the Council of Ministers at the request of the Minister of Forests, and the protection of specified species of plants and animals.

The Palatinate Committees on Nature Conservation consist of eight to twelve members and act in a similar way as the State Council, but on a county level. 
The Scientific Institution of the Polish Academy of Sciences which is combined with the Institute of Nature Conservation in Cracow, must also be mentioned. These two important institutions are concerned with the scientific aspects of nature conservation.

Besides the authorities with executive power there are the State Council and the Palatinate Committees for Nature Conservation.

The State Council, appointed through the Council of Ministers which lays down the basic lines of nature conservation, consists of thirty councillors nominated for five years, with the Minister of Forests as chairman. The councillors may be representatives of scientific or other institutions interested in the preservation of nature, or individuals active in such work. Among the duties of the Council are to give opinions on draft bills and originate motions on matters of nature conservation, to advise on the qualifications of candidates for the posts of conservators of nature and directors of national parks, and also to advise on the management of national parks and on scientific investigations therein. The Council publishes its own magazine Chronmy Przyrode Ojczysta (Let us protect nature in our country).

\section{The Nature Conservation Corps}

The official organization for the conservation of nature in Poland is completed by a voluntary unpaid conservation corps formed jointly by the League for Nature Conservation, the Tourist Society, the Hunters' Association, and the Anglers' Association. Members of the Corps, who must be over 18 years of age, are given identity cards and badges bearing the figure of the European bison. They may be authorized to impose fines for breaking regulations concerned with nature conservation. They work in conjunction with officials of national parks and if necessary with the police. An important part of their work is connected with the suppression of poaching and the prevention of the plucking and uprooting of protected plants for sale in the cities.

The Corps is at present 1,800 strong. Members are carefully selected and are given a course in nature conservation and the laws relating to it.

\section{The National Parks}

The national parks of Poland are distributed to demonstrate differences in the landscape and in natural conditions. In the Carpathian mountain chain, along the south-eastern boundary 


\section{ORGANIZATION OF \\ CONSERVATION OF NATURE IN POLAND}

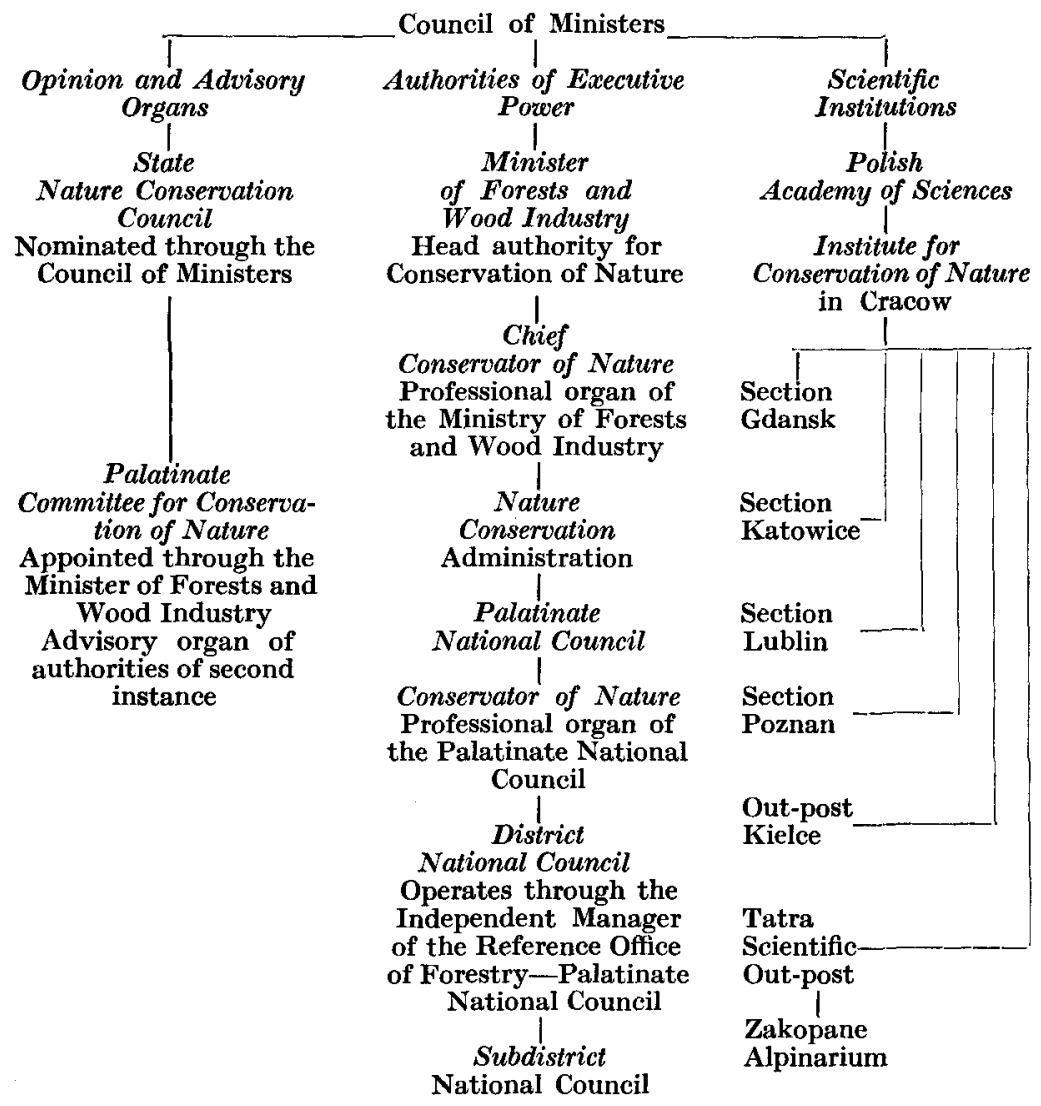

of the country, there are the Babia Góra, the Tatra, and the Pieniny national parks. In the southern highlands there are the Ojców and Sweitokrzyski national parks and, in the south-west, the most interesting parts of Poland's oldest mountains are preserved in the Karkonosze national park in the Sudeten range.

In the arcs of the great valleys extending through the middle of Poland there are three national parks, each of a different character. The Białowieza, famous for its European bison, contains a section of primeval forest ; the Kampinos, into which the elk has been re-introduced, protects forests growing on an area of dunes and bogs; the Wielkopolski covers an area of moraine forests and post-glacial lakes. 
Two other national parks which skirt the shore of the Baltic sea are of a completely different character. The Wolin comprises a fragment of island cliff and forest; the Slowiński protects beautiful shore dunes, lakes, forests, and peat bogs.

The national parks occupy the following areas, making a total of 389 square miles :-

\begin{tabular}{|c|c|c|c|c|c|c|c|}
\hline \multirow{2}{*}{$\begin{array}{l}\text { Słowiński } \\
\text { Wolin }\end{array}$} & • & . & . & • & \multicolumn{3}{|c|}{150 sq. miles } \\
\hline & & & . & $\cdot$ & 18 &, & \\
\hline Wielkopolski & . & . & . & & 18 & ," & ," \\
\hline Kampinos . & . & • & • & & 85 & ," &, \\
\hline Białowieza & . & . & • & & 20 & $"$ & \\
\hline Karkonosze $\mathbf{M}$ & unta & & & & 21. & ," & ," \\
\hline Swietokrzyski & Holy & Cross & Mts.) & & 23 & ", & , \\
\hline Ojców & & . & - & . & 6 & , & ", \\
\hline Mt. Babia Gó & & . & . & & 6 & $"$ & ," \\
\hline Pieniny Moun & ins & . & . & & 9 & ", & , \\
\hline Tatra Mount & & . & . & & 83 & . & ," \\
\hline
\end{tabular}

They employ $\mathbf{3 5 0}$ persons. Every national park has its Park Council to advise the director on the management of the park. The expenses of national parks are borne by the budget of the Ministry of Forests.

\section{BiaŁowieza}

The primeval forest of Bialowieza in the Bialystok Palatinate has existed from time immemorial and is now the only lowland forest of a primitive character in Europe. The post-glacial period, when trees first appeared, was characterized by pioneers such as birch, pine, and aspen. Later came pedunculate and sessile oaks with a marked addition of small-leaved lime and perhaps pine.

Then a gradual fall of temperature restrained the development of the oaks, and hornbeam and maple started to grow profusely. The marshy and fertile soils became covered with oak and hornbeam; dry and sandy areas developed evergreen forest.

In very ancient times Man entered the primeval forest with his settlements and colonization. Systematic exploitation of the wealth of the forest and its resources entailed a shrinking of wooded areas, lasting changes in their structure, and disturbance of the biotopes. Man's husbandry and wars left their imprint on the forest, but did not succeed in destroying it. Even now, Bialowieza reigns supreme among all European lowland forests, as a unique example of almost primeval environment and scarcely touched woodlands.

As far back as 1918, Professor Hugo Conwentz set aside the best preserved part of the primeval forest for a future " Park of Nature". This lay between the fork of the rivers Nareweka and 
Hwoźna and is now the National Park. The characteristics of the original forest with its dynamic power of natural regeneration have been preserved.

The national park gives particularly favourable conditions for research because all human interference is excluded. Its scientific value is increased because research can be conducted simultaneously in the park and in the parts of the forest used by man. Thus the influence on the forest of man and of his economic activity can be estimated.

In 1945 a Scientific Research Centre, under the direction of Professor J. J. Karpiński was formed. Thoroughly planned research work has been carried out upon climatology, soil, botany, zoology, microbiology and many other subjects. Many valuable papers have been published on the work which has been done.

The Białowieza National Park is also used for education. Exercises, practices, and courses, as well as annual excursions are organized for students of universities and colleges, teachers and school children. The scientific library and the natural history museum also serve didactic purposes.

\section{TATra}

One of the oldest documents concerning the Tatra Mountains is an act of Prince Boleslaus of Cracow, in the year 1255, conferring the privilege of hunting and fishing in the Tatra Mountains upon the Cistercian convent at Ludzimierz. In the fourteenth century, the Tatra forests became part of the royal domains and favoured individuals received privileges empowering them to found new settlements and to mine minerals.

After the third partition of Poland, in 1795, the Tatra forests were taken over by the Austrian state treasury, but on account of the low income obtained from them and difficulties in administration, they were sold in 1812 and came into private possession. Part of the forests was redeemed by the State in 1933, and the remainder was nationalized in 1945.

Endeavours to secure protection for the Tatras and their natural resources date back to the year $\mathbf{1 7 6 5}$, when a commission appointed by King Stanislaus Augustus drew attention both to waste of timber and to damage done by sheep-grazing in the forests. They proposed that the sheep be removed to other places.

Prominent Polish naturalists, such as Louis Zejszner, Maximilian Nowicki and Eugene Janota, had even in 1865 begun to urge for protection of the chamois and the marmot, and 


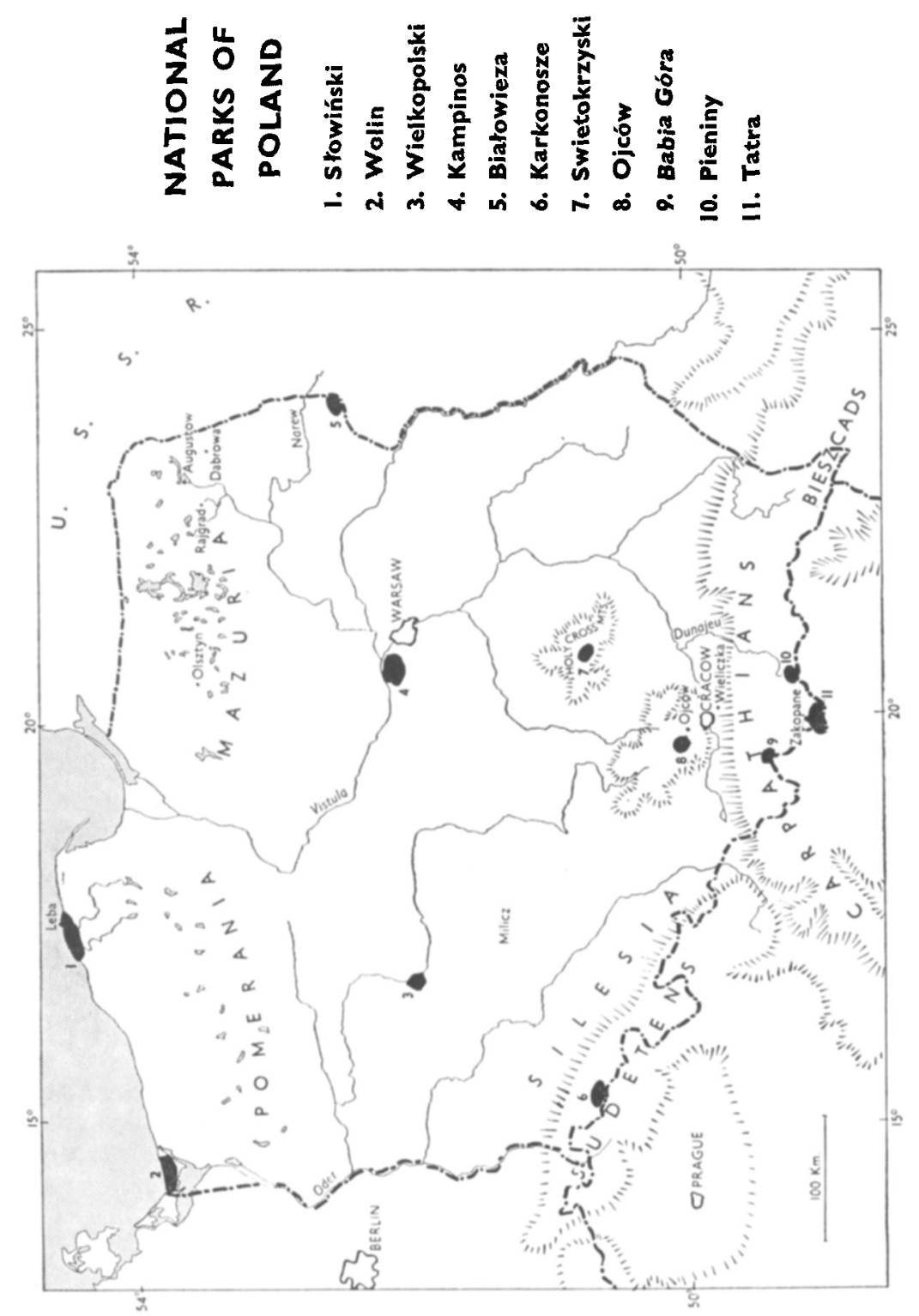


had succeeded in having a law passed that put an end to the hunting of these animals.

In 1886, the Polish Tatra Society protested against the excessive devastation of forests in the Tatra Mountains, and, in 1888 made the first proposal for a Tatra National Park, following the example of the Yellowstone National Park in North America. At the same time the Society played an important part in the action against overdevelopment of tourists' facilities that was damaging the primeval natural beauties of the mountains. But many difficulties and two world wars intervened, and it was not until 1954 that the Tatra National Park was finally proclaimed.

Vegetation.-The Tatra mountains are the highest part of the Carpathians, with an area of $\mathbf{3 0 0}$ sq. miles of which 70 sq. miles is in Poland and 230 sq. miles in Czechoslovakia. Several vegetational zones are distinguishable in the Tatras, dependent on the altitude. The lower montane zone reaches up to 4,000 $\mathrm{ft}$. above sea-level and is characterized by beech-fir forests. The upper montane zone reaches up to $5,000 \mathrm{ft}$. and is characterized by spruce forests. On a granitic substratum, between 4,000 and $5,000 \mathrm{ft}$. above sea-level, one encounters spruce forests with an admixture of the sycamore, larch, and rowan, and in some places, the stone-pine as an admixture or in the form of small stands.

The zone of the mountain-pine (Pinus mughus) reaches up to $6,000 \mathrm{ft}$. above sea-level, the alpine zone goes up to $7,700 \mathrm{ft}$., while the highest zone, the subnival one, attains the highest summits of the Tatras, $8,735 \mathrm{ft}$.

Among characteristic Tatra plants are the crocus (Crocus scepusiensis), which forms dense carpets in the Tatra meadows at the time of blossoming ; various gentians, the edelweiss, the aconite, the martagon lily, and the carline thistle.

Fauna.-Chamois (Rupicapra rupicapra) : the Tatras are the most northerly mountains of Europe in which the chamois still occurs. Their number is estimated at 100 in Poland and 780 in Czechoslovakia, a total of 880 which is thought to be fairly accurate, for counts are made simultaneously on both sides of the border. Motifs based on the chamois, especially its head and horns, occur frequently in the peasant art of the Podhale district at the foot of the Tatras.

Marmot (Marmota marmota)-It is estimated that there are some 250 marmots in the Tatras, based on observation and counting burrows. Accuracy in estimation is not possible because marmots live underground.

Brown bear (Ursus arctos).- - There are thought to be about 
30 bears in the whole of the Tatras. In the Polish part they are known to hibernate. No case of bears attacking sheep or cattle has been reported in recent years. In 1952 a male bear was drowned when the ice broke as he was crossing a frozen lake in the Valley of the Five Polish Lakes. The bear was pulled out of the lake; its skeleton and skin are now in museums at Cracow and Zakopane.

Lynx (Lynx lynx).-The European lynx was believed to be exterminated in the Tatras by 1869 , but has re-appeared and there are now five to ten lynx in the Tatras. Their presence is known each year by direct observation, by tracks and by the remains of sheep or wild animals killed by them.

The wild cat has not been noted since 1923 .

The wolf appeared in the Tatras during the second World War. During recent years wolves have killed both deer and sheep.

Birds.-The golden eagle and the lesser spotted eagle nest in the Tatras and may be seen quite frequently soaring over the mountains. The eagle owl nests there also.

The dipper and the ring ouzel are common in their respective habitats. The wall creeper is occasionally encountered on cliffs.

There are about 200 capercaillie, 200 hazel-hen, and 50 black grouse in the Tatras.

Reptiles and Amphibians.-The common adder is frequently encountered, the spotted salamander rarely so.

Nature Protection.-The 'Tatra National Park is visited yearly by about a million people, but the distribution is not evenly spaced out. During important sports events or when two holidays come together, more than 100,000 people come to Zakopane with as many as 6,000 motor vehicles. The organization of tourist traffic has to prevent the natural features of the Tatras being spoiled for this would of course destroy all their attractiveness.

During the past 35 years clear felling of the forest has been discontinued, and no great disasters have happened such as previously occurred from strong winds, heavy snowfalls or barkbeetle invasion. Part of the forests are encumbered with grazing rights for sheep and cattle which exert a very harmful effect on the forest and its fauna-chamois especially will not tolerate the presence of sheep.

In order to restrict grazing, a large part of the sheep have been transferred from the Tatras to the Bieszczads, on the basis of voluntary agreements drawn up with the peasants entitled to grazing in the Tatras. Further restrictions of grazing, and particularly the complete removal of sheep from certain alps, have contributed to the luxuriant development of vegetation 
on these ; changes in the population of insects and other animals have also been observed on them. Nevertheless, in many places the harmful consequences of grazing continue to be visible, particularly in the form of soil erosion and devastation of the vegetation. For that reason it is planned to eliminate completely grazing from a number of alps, especially the high ones.

In forests where grazing had been stopped, the forest undergrowth has regenerated, and the dense vegetation manifests no signs of devastation.

The restriction of grazing has also contributed to the protection of wild animals. With the same object, certain districts are being closed to tourists and there is frequent patrolling. During specially severe winter periods, birds and mammals are fed artificially. Within the Park boundaries there is no shooting of animals, with the exception of vagrant dogs and cats. A district with an area of some 24 sq. miles, lying just north of the Park, is excluded from normal hunting; it forms a protective zone for the animals living in the Park.

\section{SŁowríski (Kaszuby)}

The Slowinski National Park has been recently created to protect the most lovely part of the southern Baltic coast near the lakes Leba and Gardno, its boundaries are not yet fixed. Ocean currents are continually changing this coast line; the present park used to be a bay, and Lake Gardno, which is now separated from the sea by a band half a mile wide, was at the beginning of the seventeenth century a lagoon.

The area of the lakes is as follows: Leba-30 sq. miles, Gardno-10 sq. miles, Sarbskie-3 sq. miles; there are two smaller lakes-Wielkie and Mate Długie. None of them is deep ; Eeba reaches a depth of $17 \frac{1}{2} \mathrm{ft}$., Gardno $10 \mathrm{ft}$. They tend to become even more shallow since the rivers or rivulets flowing into them deposit mud as they trickle through to the sea. Lakes Leba and Gardno are only $1 \mathrm{ft}$. above sea-level. During storms the waves reverse the course of the rivers whose mouths become blocked with sand. The area of the lakes diminishes also owing to the accumulation of peat on their shores and the movement of the dunes.

The dunes.-These are the largest moving dunes in Europe, both in height and in extent : the highest, near Czołpin reaches $184 \mathrm{ft}$., Wydma Lącka $138 \mathrm{ft}$., Białe Góry $98 \mathrm{ft}$. The dunes near Lake Gardno form strange parabolas.

All types of vegetation associated with coastal dunes are found in the Słowinski National Park. 
Vegetation.-The following plants come down to the edge of the beach in winter-Honckenya peploides, Cakile maritima, Lathyrus maritimus, and the grasses Elymus arenarius, Ammophila arenaria, and $A$. baltica, whose elastic shoots and leaves hold down the sand which is blown about by the wind.

The white dunes.-This is the first line of dunes formed from sand brought up by the waves, dried by the wind and carried up onto the continent. The sand is caught up among the tufts of grass, and these little hummocks quickly build up to a height of $66 \mathrm{ft}$. Any debris from dead plants is dispersed by the strong winds so that not even a thin layer of soil is formed. On the white dunes grow grasses of the group Elyno-Ammophiletum, Eryngium maritimum, Linaria odora, Festuca rubra var. arenaria, Hieracium umbellatum var. stenophyllum, Anthyllis vulneraria var. maritima, and Petasites spurius whose large leaves fold up in times of drought. The Elyno-Ammophiletum group is important in binding the sand. Each plant of this group is perfectly adapted to extremely difficult conditions-they are able to form very long horizontal shoots, often at different levels, and thus guarantee against being buried by the sand. Their long, straight roots penetrate to the sub-soil to find water, or stretch out widely to catch rain water as it falls. All are able to protect themselves in case of prolonged drought by folding their leaves or by covering them with a layer of wax.

The grey dunes.-A little further from the coast, in places which are sheltered from very strong gusts of wind, vegetable and animal debris are able to accumulate and form a rudimentary fertile layer. These dunes thus acquire a greyish colour. Groups of Helichrysum arenarium and Jasione litoralis belonging to the Corynephoretalia begin to appear. The soil is held down by the roots of Carex arenaria and Corynephorus canescens. Salix arenaria looks strange when half covered with sand; the shoots which have managed to survive being buried jut out of the sand as if they had been planted by man. Jasione montana var. litoralis and Viola tricolor maritima are often found here. Very often the vegetation of the grey dunes is nothing but moss and lichen : Cladonia rangiferina, $\mathrm{Cl}$. silvatica, $\mathrm{Cl}$. mitis, $\mathrm{Cl}$. impexa var. condensata, $\mathrm{Cl}$. floerkana, and others, with a great deal of Cornicularia aculeata. With these grow the grasses Racomitrium canescens and Polytrichum piliferum. Roots of the plants of the grey dunes do not generally reach down to the sub-soil ; their root-system consists of many small roots spreading out to catch the rain water. 
The forests.-The Słowiński National Park portrays exactly the succession of stages in the development of vegetation from white dunes to coastal forests. The seeds of Empetrum nigrum find ideal conditions for germination and development in the shadow of the tufts of the plants of the grey dunes. They will multiply vegetatively and appear as the pioneers in the first phase of formation of the grey dunes. These pines have unusual asymetrical shapes. Other plants of these forests are the scented orchid, Listera cordata, Goodyera repens, Pirola uniflora, $\boldsymbol{P}$. chlorantha, and Linnaea borealis. The Baltic dunes have also a number of plants in common with dunes of the Atlantic coasts, such as Erica tetralix and Myrica gale.

The most attractive feature of the Słowiński National Park is the moving dunes near Leba known as "Białe Góry" (white mountains). They are difficult to climb as the sand is fine and gives way underfoot. This part is also known as the "Polish Sahara"-not such an exaggeration after all, for in the course of a walk of several miles across the dunes you may see nothing but sand and sky, except for an occasional glimpse of sea or lake. The wind blows their surface into rows of parallel pleats (ripple marks), builds huge amphitheatres of sand and high platforms. Stormy winds from the west push the dunes in an easterly direction, parallel to the coast. The rapidity of their movement has no connection with their size : they move from 6 to $10 \mathrm{yds}$. in a year. An advance of $19 \mathrm{yds}$. has been observed, but this is unusual.

Forests are completely buried and human habitations may be threatened. Near Łeba is the buried village of Lączki which was still in existence during the eighteenth century. Having buried a forest, the dunes move on, and after some tens of years it re-appears, but is now nothing but a cemetery. The dead trees have lost both bark and needles; only the stronger branches remain, polished by the passage of grains of sand, they look like ivory. Forest and heather leave behind a reddish layer $20 \mathrm{in.}$ deep.

In the National Park and near its boundaries are huge fields of different kinds of peat. On the southern borders of the park are inaccessible marshy woods of alder, inhabited by the roebuck and wild boar.

\section{Nature Reserves and Nature Monuments}

Protected areas smaller than national parks may be either nature reserves or nature monuments. Nature reserves, of which there are about 600 throughout the country, with a total area of 
about $135 \mathrm{sq}$. miles, are classified as forest, peat bog, steppe, water, geological, and other reserves, including fauna reserves. Each reserve has a special purpose, perhaps to protect some rare plant such as Dictamnus albus, the burning bush, perhaps to encourage the beaver, of which about 230 live in Poland, or perhaps to breed the little forest tarpan-type horses of which there are about 20. But most reserves fulfil several purposes.

\section{Nature Monuments}

Nature monuments are important individual natural objects or groups of objects, trees, rocks, or caves, for instance. The number registered as being under protection or deserving it in Poland amounts to 1,000 : each monument receives its registered number which appears on a board close to the object. For the benefit of tourists, county and rural district registers are kept in addition to the central ones. The registration of inanimate nature monuments has not yet been completed. Records and descriptions of destroyed monuments are kept for their historical value, for example records are kept of the " Reden ", an exposure of coal-bed in Upper Silesia which included a monolith some 14 metres high. The work of registration, revision, description, and inspection of the monuments has been carried out since 1932 by the Geological Museum (Muzeum Ziemi).

The following are striking examples of inanimate nature's monuments in Poland :- -

The Tatra mountains, where there may be found within a relatively small area a concentration of numerous exceedingly beautiful forms - the gorge of the Dunajec and the Klippen-belt in the Pieniny Range-picturesque granite buttes in the Karkonosze National Park-palaeolithic caves at Ojców-sand dunes in the Kampinoska Forest National Park (Warsaw province) and in the Słowiński National Park (Western Pomerania)-the Crystal Cave in the Wieliczka salt mine where the roofs and part of the walls of two cave chambers are coated with salt crystal druses whose edges are more than 8 in. in length-the peat bog at Dabrowa where the dwarf birch (Betula nana) survives as a relic of the tundra.

Among movable monuments may be mentioned a huge specimen of the rhinoceros (Coelodonta antiquitatis Blum) at the Natural Sciences Museum at Cracow, the silificated trunk of Araucarioxylon in the Museum of the Earth at Warsaw, and specimens of amber, some of which contain fossils of plants and animals. 


\section{Protection of Animals}

There are 383 protected animals including one mollusc, Margaritifera margaritifera, many insects, for example, bumble bees, a swallow-tailed butterfly Papillio pondalirius, and the death's head hawk moth. Salamanders, newts, and toads are protected, also lizards and several snakes. Most birds are protected including eagles, kites, buzzards, and owls, the peregrine falcon and the hobby. Among protected mammals are all shrews and bats, the stoat and the weasel, the wild cat, dormouse, brown bear, beaver, and elk (or moose), the chamois and the European bison.

Protection of these animals means that it is forbidden to catch or kill them, to destroy or damage their breeding places, to sell or buy them, to keep them, to move them from their natural habitats or export them without permission from the nature conservation authorities. The eggs, nestlings or nests of birds may not be interferred with.

The provisions do not extend to animals kept in scientific laboratories or zoological gardens. The county conservators of nature are authorized to allow the reduction of any protected animals which become pests.

\section{BrEeding}

A special section of the Nature Conservation Administration (organization of nature conservation) is devoted to the breeding of rare animals.

\section{The European Bison}

During the parts of the Pleistocene period when Asia and North America were joined where the Bering Sea now is, the bison, which lived in great numbers in Asia, were able to move into America. 'Thus, when the continents divided, two forms came into being-the European and the American bison. Although these cross easily without loss of fecundity, they are today regarded as separate species, Bison bison and Bison bonasus.

The bison has left no living descendants in Asia, for the most easterly known group of the European bison was the Caucasus herd which was first discovered in the middle of the nineteenth century and was exterminated by 1927. There is now a bison reserve at Kisha in the Caucasus; the cows are EuropeanAmerican hybrids ; a pure bred bull European bison has been introduced as a sire. 


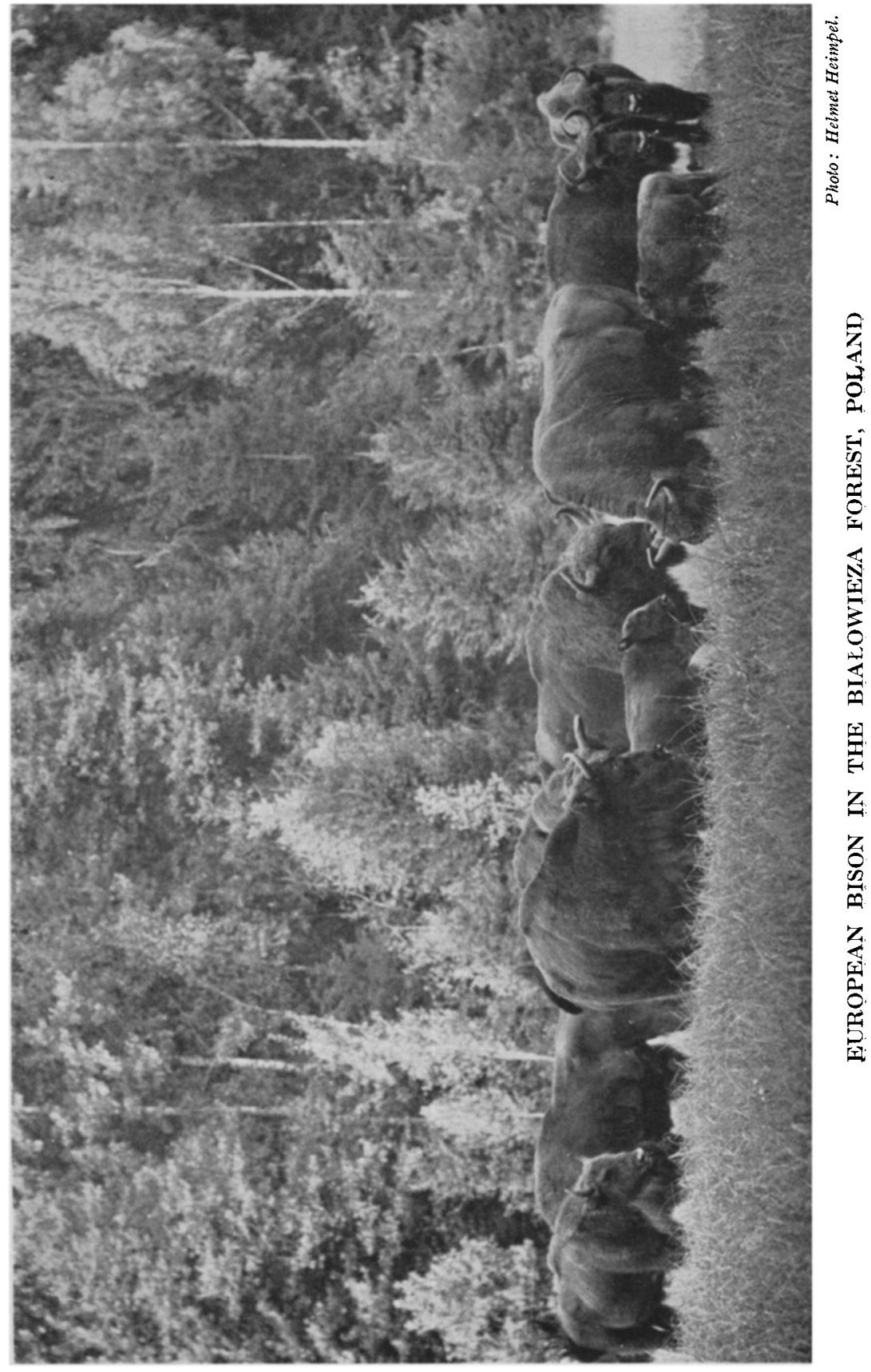


From the eighth century onwards, Europe was gradually deforested, and the forest species went with their habitat. In 1627 the last aurochs died in the Jaktorów forest reserve some 60 miles from Warsaw, and by the middle of the eighteenth century the European bison existed only in the Bialowieza forest, an area now on the border of Poland and Russia. In 1803 this forest was declared the private hunting ground of the Tsar, and the register of 1860 shows over 1,500 bison to be living there ; but by 1870, the forest having twice been the scene of fighting, only about 500 remained. From then until 1914, when the first World War started, the population had increased only to 727 in spite of careful protection. Breeding results were poor; bison cows became pregnant only about once in three years, abortions were frequent, and those calves which survived were not properly nourished by their mothers. Yet there seemed to be no lack of food, for haystacks providing for winter feeding remained only partly eaten, so that biologists began to think that the European bison was obsolescent and "must become extinct since it carries inherent germs of degeneration ".

The true reason for this degeneration was not found until much later, after the discovery of vitamins. Poor nutrition was indeed the cause of the bison's failure to breed, but quality not quantity was lacking. The Białowieza forest had not been maintained as a national park or even as a bison reserve, in accordance with modern ideas of conservation. Protection had had a single purpose-to provide game for selected persons to hunt. The forests were kept stocked with as much game of all kinds as possible-red deer, fallow deer, and roe deer. It never dawned upon anyone that the bison, so very much larger and more powerful than the other animals might fall behind in the race for nutrition. Yet they, especially the pregnant females, needed food containing large quantities of supplemental agentsvitamins. Of great importance to them, in the early spring were the shoots into which the sap was beginning to rise. In the struggle for food it was not strength, but agility that counted most. The haystacks remained to the bison and the young shoots of the first spring months (shortly before parturition, which for the bison falls in May) were devoured by the more enterprising and agile deer.

During the nineteenth century there were but few bison hunts. Far more important to the population, indeed what ultimately secured the bison's survival as a species, was the Tsar's habit of sending specimens to foreign countries as imperial gifts. For the first World War saw the extermination of the European 
bison as a wild animal. After the retreat of the Russian army, the Germans killed some $\mathbf{5 0 0}$ bison in Białowieza, and it was only towards the end of the war that they thought of taking any measures for the protection of this disappearing species. Not that any such measures would have made much difference. During the post-war confusion Bialowieza passed under Lithuanian, Polish, and then Russian rule, finally returning to Poland ; meanwhile the warfaring armies twice passed through the forests. No wonder that the remaining bison were destroyed, so that in 1921 not a single specimen could be found in this region.

This then was the situation when, as a result of proposals made by Jan Sztoleman at the International Congress for Nature Protection in 1923, the Society for the Protection of the European Bison was formed. There followed the devoted work of Dr. Erna Mohr and others in tracking down the bison in the various centres throughout Europe to which specimens had been sent and in producing the famous Pedigree Books. As a result of the Society's work, it was established that by the beginning of the second World War nearly a hundred pure bred European bison existed in Europe.

During the second World War, although the bison in some centres were eliminated, they fared quite well in others, so that in 1947, 98 remained, much the same number as before the war. Forty of them were in Poland.

Since the war the bison has increased steadily in Poland, except for casualties due to an outbreak of foot and mouth disease in 1955. By June, 1960, at the time of the I.U.C.N. conference, the total had reached 149. Of these 74 were in the Białowieza forest, 43 of them in paddocks. The remaining 31 roamed free, but under the supervision of two men. In winter, during very hard weather, they are given access to haystacks which have previously been prepared for them. Outside Poland the greatest number of bison are in the U.S.S.R. where there are about 100 , mostly in a reserve in the Russian part of the Białowieza forest. The world total in June, 1960, was about 370 .

Up to the present the paramount task has been the intensive breeding of the European bison, so that Bison bonasus should not perish from the earth. This may reasonably be said to be assured. The task of returning the bison to nature has still to be completed. This is no simple matter for the bison has lost the habit of independent living and has to be made to go wild again. Its natural environment has changed greatly, due to man's interference, and the process will certainly continue. It is hard to guess what the final attitude of the bison towards this new natural 
environment will be. Some preliminary results of the studies carried out on the free living herd in the Bialowieza forest since 1953 are highly encouraging and suggest the possibility of once again including bison as part of the wild fauna. But these are the very first steps of a long term experiment.

\section{The ELK}

Alces alces, called in Europe the elk but in Canada the moose, was almost exterminated in Poland between 1939 and 1945 . A few, however, remained in the Czerwone Bagno (Red bog) forest in the Rajgród district which was then the only remaining natural breeding place of the elk in Poland. In 1948 the elk was put under strict protection and since then its numbers have been steadily increasing. Some have even spread into the neighbouring Augustów forest.

In 1951 one male and three female elks were imported from the Soviet Union and placed in a strict reserve of about 346 acres in the Kampinos primeval forest where the elk used to live until the end of the eighteenth century. When the difficult task of rehabilitation had been accomplished the resulting population was set free and have become permanent residents in what has been declared the Kampinos National Park. By 1960 there were about 60 elk in the Park, nearly 20 of them born in 1959.

The estimated population of the elk in Poland on 1st January, 1960 , was 220 , made up as follows :-

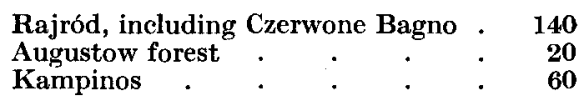

By the end of 1960 the total number of elk is expected to reach 300. The average density works out at one animal per square mile of the area the elk inhabits, but is twice as much in some parts.

An investigation in 1958 indicated that the number of males is more numerous than that of females. It has also been shown that there are two varieties of elk. One has a dark brown coat and the males have palmated antlers. The other has a blackishgrey coat with antlers not palmated, except that from about the fifth year of life the middle of the antlers broadens slightly. There is also a transition type. Antlers are shed from the end of November to March depending upon the age of the animal-the eldest shedding their antlers first.

Habitat.-The elk favours country abounding in swamps, 
lakes, and rivers, forested with alder or with a mixture of alder and ash. Sixteen plant associations have been distinguished in the Czerwone Bagno: Caricetum elatae, Caricetum gracilis, Caricetum inflato-vesicariae with Carex vesicaria, Buxbaumietum, Caricetum approprinquatae, Caricetum lasiocarpae, Betuletum humili-pubescentis, the community with Eriophorum latifolium, Saliceto-Franguletum, Alnetum glutinosae, Fraxineto-Alnetum, Querceto-Carpinetum medioeuropaeum, Pinato-Quercetum, PinetoVaccinietum myrtilli, Sphagnetum medii pinetosum, and Corynephoretum.

The Czerwone Bagno is also inhabited by other animals, for example, wild boar, roe deer, badger, fox, pine marten, and polecat. The wolf, the only natural enemy of the elk, is present also and the racoon-like dog, Nyctereutes procyonoides, which has come into the area from the Soviet Union.

Among birds nesting in the Czerwone Bagno are black stork (three or four nests), common crane, black grouse, hazel grouse, curlew, black-tailed godwit, ruff, penduline tit, and fieldfare. Close to the Forestry Headquarters there is a colony of the grey heron nesting in a beautiful wood of Scots pines.

Food of the elk.-The elk feeds on fresh water and marsh vegetation. It eats leaves and shoots of willow, poplar, rowan, and alder among soft wood trees; ash, maple, and oak among the hardwoods ; pine, spruce, and, as a last resort, larch among the conifers; buckthorn, bird cherry, strawberry and blackberry among the bushes. When wading in the water the elk consumes its favourite foods-reeds, all kinds of sedges, willow-herb, fescue grass and marsh marigold. In summer it searches for the valerian, in autumn for the nettle. In winter it feeds on the buds and shoots of woody plants, especially softwoods and conifers, and, at that time of the year, even eats bark and heather. Nevertheless, the chief food of the elk consists of all species of willow which, being rich in calcium, contribute to the development of the huge antlers of the males and strengthen the bones of the calves.

Natural history.-The female elk attains sexual maturity in about the sixteenth month of her life and gives birth to one calf, rarely two. Later, twins are almost always born. Early and prolific fecundity is characteristic of this deer. Rutting begins at the end of August and lasts till the end of September. The male mates with one female and usually covers her at sunset and daybreak or early in the morning-generally in the marshes on some solid or elevated ground. He keeps the female in a chosen territory and defends it against invasion by another male. 
Fierce fights arise between males and they often end in mutilation or even death.

The elk is said to live about twenty years. In Poland it suffers from no disease except foot and mouth disease and is very resistant even to this. When ill the elk moves with great difficulty and may fall a victim to wolves. Minor causes of death are the fighting of males at rutting time and drowning when the spring thaw comes and the ice breaks up, but these are of little significance. The chief causes of death are wolves and poaching, although wolves are only a menace when they occur in large numbers, for an elk can defend itself against a wolf. For ten years the elk enjoyed complete legal protection, but in 1959 was once more included among game animals, the number of male elk which could be shot depending upon a special licence from the Minister of Forests.

\section{The Great Eagle Owl (Bubo bubo)}

The Great Eagle Owl is an endangered species in Poland and elsewhere in Europe. Ten years ago it was not rare in Poland but its area has been gradually diminishing with the advance of industrialization and urbanization. It prefers forest regions where it may live undisturbed, and where food and hideouts are plentiful : for nesting sites it chooses rocky hollows and crevices, and even the ruins of old castles.

The Great Eagle Owl's body is $24 \frac{1}{2}-30$ in. long and its wingspan is $59-691 \mathrm{in}$. The female is larger than the male, weighing $5 \frac{1}{2} \mathrm{lb}$. to his $4 \frac{1}{2}$. Rusty-brown and black are the dominant colours of its soft plumage. On the head are two tufts of black feathers 3-31 in. high. The owl can move these tufts and even make them stand upright. They are referred to as " ears" but they have no connection with the hearing organ.

The Great Eagle Owl is monogamous ; a pair frequently take over the nest of some other bird of prey that has been left deserted, or they make a rough nest of dead leaves, pine needles and dry grass on the ground. They like to return to the same nesting place every year. The eggs are laid towards the end of March, usually two or three, more rarely four. The young take two or three years to develop fully.

Medium-sized mammals and birds form their food. This owl plays an important part in nature, eliminating excessively fruitful rodents and ill or enfeebled animals. It hides excess food in cracks between rocks or in tree-trunks to return to in times of crisis. 
The number of Great Eagle Owls in Poland today is estimated as 60-70 pairs, and most of these are found in the Carpathians. There are a few in the Pieniny mountains, in Babia Góra and in Białowieza among other places.

At one time it was fashionable to hunt with the Great Eagle Owl, and in the past it has been considered a harmful bird. Though it is hated and attacked by most birds, man has been its only serious enemy. Now all owls, with the Great Eagle Owl at the top of the list, under the decree of $\mathbf{1 9 5 2}$ of the Minister of Forests, are legally protected throughout the country. Plans are being made to reintroduce this owl in regions where it has become rare. It is proposed to make an inventory of nesting sites to facilitate protection; control of laying and sitting at each registered habitat is considered to be indispensable.

\section{The Mute Swan (Cygnus olor)}

The Mute Swan is highly regarded in Poland and its protection considered a matter of importance. Between the two world wars the population was estimated at 400 nesting pairs and 800 cygnets. By 1945 mute swans were reduced to not more than one-fifth of the pre-war stock, the rest having been shot or frightened away. Since the end of the war they have been protected and their numbers have increased steadily, an estimate for 1958 being 1,800 breeding pairs and 3,000 cygnets.

The Mute Swan is spreading to new localities as well as increasing in its former haunts. The public accept protection, with the exception of some fishermen who are hostile, and occasional tourists who do unwitting damage with their water sports and cameras. The majority of the swans nest in the Mazurian and Pomeranian lake districts, in a broad east-west belt. Others occupy detached sites to the south-the southernmost habitat is on the fish ponds near Milicz in Lower Silesia.

Several special reserves have been made, the most important being Lake Lukniany ( $2 \frac{1}{2}$ sq. miles) in the Palatinate of Olsztyn, the largest swan centre in Europe. In 1958 there were nearly 100 swan's nests on this lake, which is only 1-2 metres deep. It provides, with its surroundings, a sanctuary for many other birds, including the crane (Grus grus) and the sea-eagle (Haliaëtus albicilla).

The swan has few natural enemies; among these are the fox, wild boar and wolf ; there is also the risk of epidemics in overcrowded conditions. It is regarded as a useful bird as it helps to keep within bounds reed belts, and plants like water soldier 
(Stratiotes aloides) and Canadian pondweed (Elodea canadensis) ; also its droppings fertilize the water.

Most of the swans appear to migrate westwards in the autumn and pass the winter on the coasts of Denmark and the Netherlands, whilst others fly south to waters in central and western Poland. The majority return to their breeding grounds in March. In mild winters some birds remain at their summer quarters.

The Black Stork (Ciconia nigra) and the Cormorant (Phalacrocorax carbo) are among endangered species which have also benefited from protection.

\section{The Protection of Plants}

The Minister of Forestry's ordinance of 1957 provides for two kinds of protection for plants.

Absolute protection is given to a number of species of trees, shrubs, and herbaceous plants which may not be destroyed or removed in any form whatever, bought, sold or exported. Among these are : trees: Taxus baccata, Pinus cembra, Betula oycoviensis, Sorbus torminalis, Sorbus intermedia; shrubs : Pinus montana, Cerasus fruticosa, Daphne mezereum, and D. cneorum, Staphylea pinnata, Hedera helix, Rhododendron flavum, Chamaedaphne calyculata, Lonicera periclymenum; herbaceous plants : Osmunda regalis, Matteucia struthiopteris, Phyllitis scolopendrium, all species of Lycopodium, Trollius europaeus, Aquilegia vulgaris, all species of Aconitum, all species of Pulsatilla, Anemone narcissiflora and $A$. silvestris, Adonis vernalis, the Droserae- $D$. rotundifolia, $D$. longifolia, and $D$. intermedia, Trapa natans, Dictamnus albus, Eryngium maritimum, all species of Gentiana except G. asclepiadea, Leontopodium alpinum, Arnica montana, Carlina acaulis, and C. onopordifolia, Anthericum liliago, Lilium martagon, Fritillaria meleagris, Leucoium vernum and Galanthus nivalis, Crocus scepusiensis, all species of Iris except I. pseudoacorus, Stipa pennata and $S$. capillata, all Orchidaceae except the common red-flowered species, such as Orchis latifolia or o. incarnata.

Other plants receive partial protection. These are plants important for medicine or industry, and control is designed to protect them from excessive exploitation. Among them are : the lichens Cetraria islandica, Lobaria pulmonaria, and all species of Usnea ; gathering lichens is allowed only from trees cut in the normal course of forest management, Polypodium vulgare, Nymphaea alba, Ribes nigrum, Primula officinalis and $\boldsymbol{P}$. elatior, Arctostaphylos uva-ursi, Atropa belladonna, Asperula odorata, Centaurium umbellatum, Gentiana asclepiadea, Veratrum 
lobelianum, V. album, and V. nigrum, Colchicum autumnale, Convallaria maialis, Carex arenaria, Hierochloë odorata.

Protection of species of plants is a help up to a certain point, but endemic plants are often threatened by various forms of development which interfere with their habitat. Cases of this were the disappearance of lovely meadows of Crocus near Zakopane through ploughing, and the destruction of most of the localities favourable to Gladiolus parviflorus near Cracow through improvement of damp meadows. If the drying of meadows continues, the endemic Pinguicula bicolor will be exterminated. The majority of endemic species in Poland grow on mountainous ground in national parks where their protection is assured; Larix polonica and Carlina onopordifolia, for instance, benefit from the protection of a complete reserve. When they grow elsewhere, it is recommended that careful thought and consideration of biological factors should be taken before changing the present method of exploiting the land, otherwise economic loss may result. A plant may be of great potential value that is undreamt of today.

Twenty-six steppe and steppe-and-forest reserves exist in Poland, and projects for creating 33 more are under consideration.

\section{LITERATURE}

Ferens, B., Uggla, H., and Wolak, J., 1960. The Elk Reserve, Czerwone Bagno. Makkowskr, S., 1960. On Monuments of Inanimate Nature in Poland, Polish Academy of Sciences, Warsaw.

Rzyszczewski, S. J., 1960. The elk and its protection in Poland.

SzCzesny, T., 1960. The nature conservation corps in Poland.

and the following booklets published in 1960 by the State Council for Conservation of Nature, Warsaw, Poland.

1. The Mute Swan in Poland, by J. Sokołowski.

2. Le Hibou Grand-Duc en Pologne, by B. Ferens.

3. Le Pare National Słowiński, by T. Wojterski.

4. The Tatra National Park, by M. Marchlewski.

5. Conservation of Natural Resources, by W. Goetel.

6. Poland's Steppe Vegetation and its Conservation, by A. MedweckaKornaś.

7. Some Species of Birch endemic in Poland, by J. Jentys-Szaferowa.

8. The State and Organization of Nature Conservation in Poland, by T. Szczesny.

9. The European Bison, by J. Zabinski.

10. The European Bison, by K. Krysiak.

11. The Peininy National Park, by S. Smólski.

12. National Parks in Poland, by $\mathbf{S}$. Gut.

13. Les Espèces Endémiques en Pologne, by St. Pawlowska.

14. The Białowieza National Park, by R. Pachlewski.

15. Le Pare National d' Ojeów, by S. Gut.

16. The Forest Reserve Swinia Góra, by S. Barański, L. Bober, B. Adamczyk, J. Fabijanowski, M. Kuc, J. Nowak and L. Pomarnacki. 